\title{
Collaborative Problem Based Learning Model for Creative Thinking Ability
}

\author{
Rusly Hidayah ${ }^{1,2}$, Fauziatul Fajaroh ${ }^{2}$, Parlan $^{2}$, I Wayan Dasna ${ }^{2}$ \\ Corresponding Email: ruslyhidayah@unesa.ac.id
}

${ }^{1}$ Faculty of Mathematics and Natural Sciences, Universitas Negeri Surabaya, Indonesia

${ }^{2}$ Faculty of Mathematics and Natural Sciences, Universitas Negeri Malang, Indonesia

Received: July 11, 2021

Revised: August 25, 2021

Accepted: September 6, 2021

\begin{abstract}
This study discusses Problem-Based Learning effect in shaping students' creative thinking ability. the study uses existing literatures in sending forth a comprehensible construction of the method. In developing student creativity, it is still a topic of discussion from various experts, especially at the university level, which is related to the optimization of the right brain as a student which is used to increase creativity and imagination. With this assumption, it is imperative in efforts to develop creativity for students that it is very important to pay attention to. Students can face challenges for their future if they master chemistry as a reference point. In learning chemistry as a student, you must have the ability to think creatively to solve these problems. This research aims to improve the chemistry learning process at the university level, especially for students by using a method. The topic in this discussion aims to find out the content and discussion of the application of student collaborative problem based learning methods in the chemistry learning process at the university level.
\end{abstract}

Keywords: Collaborative, CPBL, College, Creativity

\section{Introduction}

Progress in education in a country is known to be one of the factors that influence the progress of that country. This learning is one of the functional communication processes between students and educators and other students. Education is a path full of beauty and a path that builds civilization for the prosperity or progress of a nation. Competitive power in there is a relationship that is determined by the creativity of human resources in the nation. Creativity is needed in every space of life in order to provide an art of life, create a change, and solve every problem in order to improve the quality of one's life. With this connection in the field of education, it must be directed so that it can become a human being who has its own qualities to be able to compete, but of course it must be based on having noble character and excellent morals.

In universities, which are the highest educational institutions in Indonesia, it is known that they have separate demands for graduation because this is one of the related efforts as an increase in the nation's competitiveness. Law No. 12 in 2012 on Higher Education, and National Education System Law No. 20 in 2003 is related to the achievement of student competencies who have creative thinking. In addition, during lectures, students are expected to be able to understand a concept during the learning process in each assigned subject and be able to solve the problem using the knowledge and skills in creative thinking that the student has.

Chemistry has 2 interrelated things, namely chemistry as a product in the form of concepts, facts, principles, theories, and laws, and chemistry as a process or scientific work. Based on the characteristics of the chemistry learning process, it will always be related to the facts and concepts of chemistry in everyday life. However, the facts in the field are that students only 
understand concepts in chemistry which are only based on the form of textbooks and explanations from the teacher so that students do not know about the relationship between chemical concepts in everyday life. This is evidenced by research by Pardhan \& Mohammad, (2005) in their research it is explained that teachers provide their knowledge only by talking in front of the class, this makes students difficult to understand concepts and answer problems discussed by the teacher. As a teacher, it is obligatory to present meaningful chemistry lessons so that students become interested in learning these lessons in order to prepare them for the global era of competence.

In chemistry learning, this learning has the aim of training reasoning and thinking patterns to get a conclusion, including: exploring, showing similarities, experiments, consistent and inconsistent, and differences. The level of student persistence in solving a problem is still relatively low so that it has an influence on the ability of their creative thinking power (Nursa'adah \& Rosa, 2016).

In an effort to build civilization for the advancement of a nation, the learning process needs to be supported by creativity that is linked to personal experience by observing, reasoning, asking questions, working in groups, and solving problems. According to Jacob, (2012) revealed that solving a problem of skills and skills by thinking critically is one unit that cannot be separated. Therefore, the chemistry learning process in universities must be considered and emphasize the chemistry learning process that influences and improves students' mindsets in an effort to deal with a problem. In addition, efforts that can improve understanding (knowledge) in the student learning process are the collaborative problem-based learning method. With this, students can learn with problem-based methods in groups.

\section{Literature Review}

\section{Creative Thinking}

Creativity is an element that is very influential, especially for students as a marker of the continuity of their lives later. According to Adams, (2005) why creativity must be developed for someone, especially students, namely: (1) by being creative, a person or student can realize the nature in himself (self actualization) this is a need to realize human nature, (2) formal education is one of the factors known to increase the creative process of a person, (3) having a useful self-interest and giving satisfaction to oneself with the creative side that is generated, (4) creativity is one way for a person to have a good impact in his life. In this case, it is necessary to realize that our known predecessors have greatly helped humans with their creative thinking so that we can solve various kinds of problems that are not yet known.

Creativity can be used as an assessment of potential benchmarks for the quality of human resources (HR). In addition, creativity is a potential whose development cannot be separated from psychological and social aspects. Psychological aspects are related to the mindset, as well as a person's mentality.

\section{Collaborative Problem Based Learning Method}

The method in the collaborative learning process is a method that applies a new paradigm in learning theories, namely constructivism. According to Ellis \& Orchard, J. (2014). that the idea of learning is a social experience (Patten \& Newhart, 2017) revealed that the ability to think individually can create personal meaning, after which they tested the results of their thinking skills with other dialogues to match the understanding they were discussing. With these ideas, students can simultaneously build understanding collectively by describing the meaning discussed in a wider group.

Collaborative learning is based on Piaget's theory, namely Constructivist Theory which is associated with the idea of Active Learning. It is believed that students will learn better if they 
are able to think in groups, process ideas, and present ideas by presenting the results of their ideas in front of the class. In addition, they are encouraged with other students to think together, and they will certainly be more interested in the learning process. Behind this, regarding the topic of membership in a group during the teaching and learning process, according to Schulz et al. (2015) members in the group will be more active in the learning process if they learn with relevant materials or models as a reference for their creative ideas. Especially for those who are driven physically as well as mentally as this will make their thinking power visible and influential for others. Students will experience more improvement through their imagination and creative mindset compared to learning from a speech. The movement from an individualist meaning to a shared meaning is one of the motivating factors when students construct a representation of their thinking.

According to Summers (2006). there are three theories that are known to have an effect on collaborative learning, namely the theory of constructivism, motivation, and cognitive. Cognitive theory is concerned with the exchange of ideas between students who are grouped during collaborative learning, it becomes a reference as a transformation of knowledge that will affect every other member in the group. In constructivism theory, it is related to the existence of social interaction between group members which will improve the individual and form a pattern of mutual respect between the opinions of all members in the group. And the theory of motivation is designed on a path of collaborative learning, because the process of this learning method will affect a conducive environment for students to gain knowledge, and students will increase their courage towards all members for them to give an opinion, and have a situation where students will need each other in the group.

\section{Chemistry Lessons in College}

According to Sirhan (2007) chemistry is a branch of the natural sciences and one of the many sciences that have advantages for students to learn. In addition, chemistry is one aspect of everyday life which includes activities when we drink, eat, take medicines, clothes, etc. In addition, chemistry is known to have a contribution in an effort to solve a problem that includes problems in the real world which are complex in nature and explain a lot about phenomena that occur in everyday life so that this cannot be separated in human life. The benefits of chemistry must be learned when we are in junior high school, high school, then continue to college level. In chemistry lessons in college, the relationship is in nature and life which includes composite structures, as well as the properties and changes or energy involved. Chemistry also understands the structure of a material and the changes that matter undergoes in nature and in the experiments to be planned (Keenan, Kleinfelter, and Wood, 1984).

According to Tan and Treagust, there are difficulties or obstacles during the chemistry learning process in college, namely the student's environmental factors as well as learning difficulties and errors in understanding concepts when participating in learning at the high school to college level. Likewise, difficulties in studying chemistry are errors in learning, this is the core and basis for further chemistry studies or supporters of natural science and others. In addition, the results of research by Mihardi et al. (2013) indicate that further research is needed as an effort to improve learning models related to inquiry with a learning system that can attract students to have an in-depth and creative mindset through investigative activities. in the laboratory. Educators or teachers must present a meaningful chemistry learning model so that the younger generation will be interested in studying chemistry very freely in order to prepare for the era of globalization.

\section{Methods}

This study uses a literature review method. The literature review is a summary that includes several aspects derived from several previous researchers with various topics. The literature in this research comes from scientific articles, books, theses, and journals. Literature review is one

Copyright $(\odot$ 2021, Journal of Asian Multicultural Research for Educational Study, Under the license CC BY-SA 4.0 
of the activities that obtains, includes and studies the contents of research reports and related discussions as research plans. In this study, it is intended as knowledge in the effectiveness of collaborative problem-based learning in order to improve chemistry learning in universities

\section{Results and Discusssion}

\section{Characteristics of Collaborative Problem Based Learning}

Abbas et al. (2019) stated that the characteristics of collaborative learning includes Interaction, Positive Addiction, Development of Interpersonal Skills, Individual or Group Accountability, Knowledge Sharing Between Teachers and Students, Formation of Heterogeneous Groups, Teacher as Mediator, Sharing Authority Between Teachers and Students.

\section{Learning Strategies Collaborative Problem Based Learning}

The collaborative problem based learning learning model has a strategy that is suitable to be used to further develop basic reasoning skills, critical thinking skills, problem solving abilities and students' mathematical communication skills due to several reasons.

To begin with, in the PBL method, the premise of the conversation during lectures is related to the existence of a problem to be solved, it forces students to focus and concentrate in a group in solving the problem. To solve the main problems given by lecturers to students, as students, they must explain the basis of their understanding separately and criticize ideas or ideas against their colleagues, and choose an answer framework and deal with various problems given. must be carried away in an effort to improve the student's ability to think critically or creatively.

Furthermore, By utilizing methods in collaborative learning, as students can learn in groups with a certain amount in order to exceed the limits of the creative thinking of students when answering various kinds of chemistry problems given by the lecturer. Learning in this way focuses on student social interaction activities by means of discussion or dialogue, as well as exchanging opinions to improve student understanding as a whole. In the form of collaboration, this is one part of the way to improve students' reasoning, understanding, and problem solving.

\section{Advantages of Collaborative Problem Based Learning Model in Chemistry Learning}

In the process of learning chemistry in universities, it is identified with dynamic thinking given pictures. In addition, students can acquire and develop knowledge of chemistry based on experiments to find answers to questions related to the how, what, and why elements of normal miracles which are particularly related to the structure, composition, transformation, properties and energetics of substances that can affect ductility and reasoning. college student. With the CPBL method, this learning method is known to have its own differences with the group learning method. The advantages of this method are that by learning collaboratively students can be motivated to do their best, by learning collaboratively as a student they can influence other students, and by learning collaboratively it can significantly improve student achievement. (khairani et al., 2020). Members in a group will be more flexible when students are guided by a learning method that has materials or models to interpret how they think (DaHong et al., 2020).

In collaborative learning based on solving a problem is one approach to learning related to contextual problems so that it can stimulate the brain and mindset of students to learn together (in groups). In classes that apply learning methods based on solving a problem, students work together in teams or groups to solve real-life problems.

The various steps in carrying out problem-based learning methods are:

\section{Have a Basic Concept}

The steps required to apply the concept of problem-based learning are the facilitator providing instructions, skills, and instructions. The point is that students understand more quickly the

Copyright (C) 2021, Journal of Asian Multicultural Research for Educational Study, Under the license CC BY-SA 4.0 
atmosphere of the material they are going to learn and get an accurate flow of directions and goals in the learning process.

\section{Explanation of a Problem (Defining theProblem)}

In the problem definition step, the facilitator is expected to interpret the main points of the problem. And as students and all members in the group are expected to carry out activities that make them find the path as answers to the main problems made by the facilitator so that students can find out how they can express their opinions alternatively.

\section{Self-Learning}

In the independent learning step, students are expected to look for sources that are expected to be able to understand the concepts that they will learn, the various sources that are sought are sources that have weight on broader knowledge to be investigated. And in the investigation stage, the main thing is that students are expected to seek this information and develop the understanding that they have discussed with their groups. In addition, making a presentation in front of the class is very important if the information has been collected into one, and the condition of the information is relevant information so that it is easy for students to understand the information.

\section{Knowledge Exchange}

If students have obtained various sources to understand the concepts in the previous step, at the next meeting students are expected to discuss in their groups as a clarification of their achievements and find a solution to the problems of the group. With the exchange of ideas between students in groups, students are expected to gather with their respective groups to answer questions from the facilitator.

\section{Assessment}

The assessment that will be carried out is combined with three aspects, namely skills, attitudes, and knowledge. In addition, this is very important in learning chemistry for students because of prior knowledge, as well as the existence of different sources. With the collaboration, students will complement each other on the problems they will solve.

Collaborative method is one method where students can work together in a group in order to solve various kinds of problems with the same goal. Students are expected to be able to carry out the learning process in groups because basically grouping is not the main goal but how students' individual knowledge can be constructed through collaborative learning. With the grouping for the teaching and learning process, according to constructivism, it is one strategy that is highly recommended for students to share opinions, argue, and develop various alternative ways of viewing in an effort to construct student knowledge individually. In addition, this collaborative learning method is very effective in the chemistry learning process which allows sharing of information between students. In collaborative learning, students can work together in small groups to express an idea or ideas that are broad or more creative in the chemistry learning process.

\section{Development of Collaborative Problem Based Learning Model}

Researchers have designed a learning model based on theoretical and empirical studies so that the following learning models are formed: 1) Student orientation; 2) Scientific activities; 3) Presentation of the results of scientific activities; 4) Completion of critical thinking tasks; and 5) Evaluation. In this model students are required to be proactive in scientific activities to practice critical thinking skills and self-efficacy so that the chemistry learning model developed is called Scientific Critical Thinking learning (Rusmansyah, et al. 2019). The SCT model is designed with the ultimate goal of practicing critical thinking skills and self-efficacy. 
Then the development carried out by Fuad, et al (2019), showed that the GSL (Group Science Learning) model was effective in increasing the collaborative problem solving skills and confidence of elementary school teachers. This research is indeed an alternative to overcome 21 st century problems related to low-level collaborative problems in solving skills and confidence in basic chemistry courses, so further research is needed to apply the GSL model at the university level.

If it is associated with the problems mentioned earlier and also seen from the characteristics and strategies regarding the problem-based collaborative learning model (Collaborative Problem Based Learning), the SCT and GSL models when combined with the collaborative problem based learning learning model are expected to increase creativity and students' critical thinking patterns so that the next generation is obtained in the hope that it can have a positive impact on the nation.

Some of the benefits of adopting PBL include the ability to engage in a very wide discussion of the subject, highly active debates, and the ability to build critical thinking skills in the process. With the application of PBL learning, students can develop critical thinking skills such as the ability to identify and analyze problems, as well as the ability to come up with creative solutions to problems, the ability to ask questions or criticize problems from other groups, the ability to answer questions and express opinions during presentations with appropriate learning $\mathrm{r}$, and the ability to use appropriate learning $\mathrm{r}$ to develop critical thinking skills. Although critical thinking skills may be developed through time, there are still some pupils who are categorized as having poor critical thinking abilities. They have difficulty expressing their views because they are still ashamed and have not had the chance to explain why they feel embarrassed. It seems that almost all of the pupils were able to evaluate and identify the issues they faced. Some of them, on the other hand, are still unable to identify the most appropriate alternate solution to a problem. While the advantages of PBL outweigh the disadvantages, some of the disadvantages include the time it takes to implement, the fact that learning needs individual learning activities for each student, and the fact that some students still rely on their group members.

\section{Conclusion}

Collaborative problem-based learning is one of the most effective problem-based group learning methods for students when studying chemistry in college. With the creative thinking that a student has, this can improve the perspective of how the student overcomes the problems that will be solved or completed. In addition, the group is one of the important factors in this method, because this method is needed so that students can exchange their creative ideas with each other.

\section{Thank-You Note}

The authors would like to thank the Universitas Negeri Surabaya. This research was supported by a doctoral dissertation grant and is part of a research entitled: Development of Collaborative Problem Based Learning Strategies

\section{References}

Abbas, J., Aman, J., Nurunnabi, M., \& Bano, S. (2019). The impact of social media on learning behavior for sustainable education: Evidence of students from selected universities in Pakistan. Sustainability, 11(6), 1683

Adams, K. (2005). The Sources of Innovation and Creativity. National Center on Education and the Economy (NJ1). 
Da-Hong, L., Hong-Yan, L., Wei, L., Guo, J. J., \& En-Zhong, L. (2020). Application of flipped classroom based on the Rain Classroom in the teaching of computer-aided landscape design. Computer Applications in Engineering Education, 28(2), 357-366.

Ellis, V., \& Orchard, J. (2014). Learning teaching "from experience": Towards a history of the idea. Learning teaching from experience: Multiple perspectives, international contexts, $1-17$.

Fuad, A., Alfin, J., Fauzan, F., Astutik, S., \& Prahani, B. K. (2019). Group Science Learning model to improve collaborative problem solving skills and self-confidence of primary schools teacher candidates. International Journal of Instruction, 12(03).

Jacob, S. M. (2012). Mathematical achievement and critical thinking skills in asynchronous discussion forums. Procedia-Social and Behavioral Sciences, 31, 800-804.

Keenan, C.W., Kleinfelter, D.C., \& Wood, J.H. (1984). Kimia untuk Universitas, Jilid 1 (6th ed.). Jakarta: Erlangga.

Khairani, S., Suyanti, R. D., \& Saragi, D. (2020). The Influence of Problem Based Learning (PBL) Model Collaborative and Learning Motivation Based on Students' Critical Thinking Ability Science Subjects in Class V State Elementary School 105390 Island Image. Budapest International Research and Critics in Linguistics and Education (BirLE) Journal, 3(3), 1581-1590.

Mihardi, S., Harahap, M. B., \& Sani, R. A. (2013). The effect of project based learning model with kwl worksheet on student creative thinking process in physics problems. Journal of Education and Practice, 4(25), 188-200.

Nursa'adah, F. P., \& Rosa, N. M. (2016). Analisis kemampuan berpikir kreatif kimia ditinjau dari adversity quotient, sikap ilmiah dan minat belajar. Formatif: Jurnal Ilmiah Pendidikan MIPA, 6(3).

Pardhan, H., \& Mohammad, R. F. (2005). Teaching science and mathematics for conceptual understanding? A rising issue. Eurasia Journal of Mathematics, Science and Technology Education, 1(1), 1-20.

Patten, M. L., \& Newhart, M. (2017). Understanding research methods: An overview of the essentials. Routledge.

Rusmansyah, R., Yuanita, L., Ibrahim, M., Isnawati, I., \& Prahani, B. K. (2019). Innovative chemistry learning model: Improving the critical thinking skill and self-efficacy of preservice chemistry teachers. JOTSE: Journal of Technology and Science Education, 9(1), 59-76.

Schulz, K. P., Geithner, S., Woelfel, C., \& Krzywinski, J. (2015). Toolkit-based modelling and serious play as means to foster creativity in innovation processes. Creativity and innovation management, 24(2), 323-340.

Sirhan, G. (2007). Learning Difficulties in Chemistry: An Overview. Turkish Science Education, 4(2), 1.

Summers, J. J. (2006). Effects of collaborative learning in math on sixth graders' individual goal orientations from a socioconstructivist perspective. The Elementary School Journal, 106(3), 273-290. 